Témoigner Témoigner. Entre histoire et mémoire

Getuigen Revue pluridisciplinaire de la Fondation Auschwitz

$115 \mid 2013$

L'Espagne en construction mémorielle

\title{
Bibliographie et sitographie sélectives
}

Selective bibliography and sitography

Selectieve bibliografie en sitografie

(2) OpenEdition

Journals

Édition électronique

URL : http://journals.openedition.org/temoigner/484

DOI : $10.4000 /$ temoigner.484

ISSN : 2506-6390

Éditeur :

Éditions du Centre d'études et de documentation Mémoire d'Auschwitz, Éditions Kimé

Édition imprimée

Date de publication : 1 mars 2013

Pagination : 108

ISBN : 978-2-84174-628-6

ISSN : 2031-4183

Référence électronique

«Bibliographie et sitographie sélectives », Témoigner. Entre histoire et mémoire [En ligne], 115 | 2013,

mis en ligne le 01 juin 2015, consulté le 23 octobre 2020. URL : http://journals.openedition.org/

temoigner/484; DOI : https://doi.org/10.4000/temoigner.484

Tous droits réservés 


\section{Bibliographie \& sitographie sélectives}

Paloma Aguilar, Memoria y olvido de la Guerra Civil español, Madrid, Alianza, 1996.

Julio Aróstegui, « La mémoire de la guerre civile et du franquisme dans l'Espagne démocratique », Vingtième Siècle, Revue d'Histoire, n 74, 2004, p. 31-42.

Julio Aróstegui, François Godicheau (dir.), Guerra Civil. Mito y memoria, Madrid, Marcial Pons, 2006.

Equipo Nizkor, "La cuestión de la impunidad en España y los crímenes franquistas". http://www.derechos.org/nizkor/espana/doc/ impuesp.html. Leido 12/II/2005

Carlos Forcadell et al., Usos de la historia y políticas de la memoria, Zaragoza, Prensas Universitarias de Zaragoza, 2004.

Gobierno de Cataluña, Llei del Memorial Democràtic, Barcelona, Gobierno de Cataluña, 2006.

http://10.gencat.net/drep/AppJava/cat/ Memorial/projecte.jsp. Leído 1/IV/2005

Santos Juliá, “Echar al olvido. Memoria y amnistía en la transición", Claves de razón práctica, $n^{\circ} 129,2003$, p. 14-24.

Santos Juliá (coord.), Víctimas de la Guerra Civil, Madrid, Temas de Hoy, 1999.

José Madalena Calvo et al., "Los lugares de la memoria de la Guerra Civil en un centro de poder. Salamanca 1936-39", in Julio Aróstegui (coord.), Historia y memoria de la Guerra Civil, Valladolid, Junta de Castilla y León, 1998, t. II, p. 487-549.

Juan Sisinio Pérez Garzón (dir.), La gestión de la memoria. La historia de España al servicio del poder, Barcelona, Crítica, 2000.

Paul Preston, The Spanish Holocaust, New York, W.W. Norton \& Company, 2012.
Joan Ramon Resina (dir.), Disremembering the Dictatorship. The Politics of Memory in the Spanish Transition to Democracy, Amsterdam/ Atlanta, Rodopi, 2000.

Emilio Silva, Santiago Macías, Las fosas de Franco. Los republicanos que Franco dejó en la cuneta, Madrid, Temas de hoy, 2003.

Francesc Torres et al., "Dossier : Fosses Comunes. La memòria soterrada", L 'Avenç, $n^{\circ} 299,2005$, p. 19-43.

Rafael R. Tranche, Vicente Sánchez-Biosca, NO-DO. El tiempo y la memoria, Madrid, Cátedra, 2001.

Ricard Vinyes, “La metàfora de bronze. El procés de monumentalizació a J. Verdaguer (1902-1924)", Spagna contemporanea, n 11 , 1997, p. 65-86.

Ricard Vinyes (coord.), Un Futuro para el Pasado. Proyecto de creación del Memorial Democrático, Barcelona, Gobierno de Cataluña, 2004.

http://www10.gencat.net/drep/AppJava/cat/ Memorial/index.jsp.Leído 4/IV/2005

Ricard Vinyes, Montse Armengol, Ricard Belis, Los niños perdidos del franquismo, Barcelona, Plaza y Janés, 2002.

Ulrico Winter, "From Post-Francoism to Post-Franco Postmodernism. The 'Powers of the Past' in Contemporary Spanish Narrative Discourse (1976-1992)", in Eloy Merino, H. Rosi Song (dir.), Traces of Contamination. Unearthing the Francoist Legacy in Contemporary Spanish Discourse, Lewissbug, Buknell University Press, 2005. 